\title{
REACTION OF Crambe abyssinica TO Meloidogyne javanica AND M. incognita RACE $3^{1}$
}

\author{
RAFAEL ASSIS DE SOUZA ${ }^{2 *}$, REGINA CÁSSIA FERREIRA RIBEIRO ${ }^{3}$, LEANDRO DE SOUZA ROCHA $^{4}$, \\ ADELICA APARECIDA XAVIER ${ }^{3}$, ISAC PEREIRA SOARES MARTINS ${ }^{5}$, FABÍOLA DE JESUS SILVA $^{6}$
}

\begin{abstract}
Several oilseed plants have been researched for biodiesel production in Brazil, and Crambe abyssinica Hochst is one of the most promising species. The effect of the phytonematodes $M$. incognita race 3 and Meloidogyne javanica on C. abyssinica plants was evaluated in greenhouse experiments. A randomized block design with five nematode inoculum levels (350, 700, 1400, 2800, and 5600 eggs) and ten replications was used. C. abyssinica plants without inoculation were used as controls, and the viability of the nematodes used was tested in tomato plants inoculated with 2000 eggs. The plots consisted of pots containing one plant. The number of root knots (NG), number of egg masses (NEM), and number of eggs + second-stage juveniles (NEJ2) per root system, number of $J 2$ per $200 \mathrm{~cm}^{3}$ of soil (NJ2), and shoot dry weight (SDW) of the inoculated C. abyssinica plants were evaluated at 45 days after inoculation. The reproduction factor (RF) of the nematodes was also evaluated. The resistance of the plants to the phytonematodes was classified using the RF criterion. Crambe abyssinica plants are susceptible to the different inoculum levels of Meloidogyne javanica and $M$. incognita used, and the data of all nematode variables (NG, NEM, NEJ2, NJ2, and RF) were fitted by linear models.
\end{abstract}

Keywords: Root-knot nematodes. Susceptibility. Crambe.

\section{REAÇÃO DE Crambe abyssinica A Meloidogyne javanica E M. incognita RAÇA 3}

RESUMO - Dentre todas as oleaginosas que estão sendo pesquisadas atualmente no Brasil para produção de biodiesel, o crambe, Crambe abyssinica Hochst, vem se revelando como uma das mais promissoras. Neste trabalho estudou-se a reação de crambe aos fitonematoides Meloidogyne javanica e M. incognita raça 3, em casa-de-vegetação. Para os ensaios adotou-se o delineamento em blocos casualizados com cinco níveis de inóculos (350, 700, 1400, 2800 e 5600 ovos) e dez repetições. Plantas de crambe sem inoculação de ovos foram usadas como controle e para comprovar a viabilidade dos inóculos dos nematoides usou-se tomateiros inoculados com 2000 ovos. A parcela constituiu-se de um vaso contendo uma planta. Após quarenta e cinco dias da inoculação dos nematoides, determinou-se o número de galhas, de massas de ovos e de ovos+ juvenis de segundo estádio (J2) por raiz, o número de $\mathrm{J} 2$ por $200 \mathrm{~cm}^{3}$ de solo e o peso de matéria seca. Determinou-se também o fator de reprodução (FR). A classificação da resistência aos fitonematoides foi feita utilizando o critério do fator de reprodução (FR). O crambe comportou-se como suscetível em todos os níveis de inóculo e observou-se ajuste do modelo linear para todas as variáveis nematológicas (galhas, massas, J2, ovos e FR) avaliadas.

Palavras-chave: Nematoides das galhas. Suscetibilidade. Crambe.

\footnotetext{
*Corresponding author

${ }^{1}$ Received for publication in $09 / 05 / 2017$; accepted in 12/04/2018.

Paper extracted from the Course completion work in Agronomy of the first author.

${ }^{2}$ Post-Graduate Program in Plant Production, Universidade Federal do Espírito Santo, Alegre, ES, Brazil; souza.rafaelassis@gmail.com ORCID: 0000-0002-8216-7431.

${ }^{3}$ Department of Agrarian Sciences, Universidade Estadual de Montes Claros - Janaúba, MG, Brazil; regina.ribeiro@unimontes.br - ORCID: 0000-0001-5138-8402, adelica@unimontes.br - ORCID: 0000-0001-9814-4587.

${ }^{4}$ Embrapa Mandioca e Fruticultura, Cruz das Almas, BA, Brazil; leandro.rocha@embrapa.br - ORCID: 0000-0002-8759-4846.

${ }^{5}$ M.Sc. in Plant Production in the semi-arid, Universidade Estadual de Montes Claros - Janaúba, MG, Brazil; agronomoisac@gmail.com ORCID: 0000-0002-2079-9556.

${ }^{6}$ Post-Graduate Program in Phytopathology, Universidade Federal de Lavras, Lavras, MG, Brazil; fa.agronomia@gmail.com - ORCID: 0000-0002-1734-6521.
} 


\section{INTRODUCTION}

Crambe abysinica Hochst is an oilseed species of the Brassicaceae family, is indigenous to Ethiopia and was domesticated in Mediterranean regions. This species is very promising for biodiesel production in Brazil because of its high seed oil content (34\%) (REGINATO et al., 2013). The oil from $C$. abyssinica seeds is important to chemical industries because of its high content of erucic acid. This oil is used in lubricants, adjuvants for pesticide applications, and as a glidant in plastic alloys (AIR, 1997). The use of this oil for biodiesel production is advantageous because it presents low melting point $\left(-12{ }^{\circ} \mathrm{C}\right)$ and high oxidative stability (PITOL; BROCH; ROSCOE, 2010).

In addition, $C$. abyssinica seed oil extraction generates a byproduct that can be used for nematode control; this byproduct contains glucosinolates, which degrade and release isothiocyanates and epiprogoitrin that present suppressive action on phytonematodes of the Meloidogyne genus (WALTER, 1996).

C. abyssinica crops present early-maturing plants (mature grains at 90 to 100 days), good productivity (up to $2500 \mathrm{~kg} \mathrm{ha}^{-1}$ ), adaptation to different pedoclimatic conditions, and uniform maturation, which facilitates mechanized harvesting (FALASCA et al., 2010). This crop requires the same structures of soybean crops, such as seeders, harvesters, and warehouses. Thus, C. abyssinica is a promising alternative to secondary crops in the Central-West region of Brazil (ROSCOE; DELMONTES, 2008), especially, for soybean and corn producers who use crop rotation systems.

Crop rotation is one of the strategies used to manage soil pathogens such as fungi and bacteria that survive on crop residues and phytonematodes. Phytonematodes of the Meloidogyne genus are difficult to control because of their wide spread distribution and wide range of hosts (FREITAS; FERRAZ, 2007). Thus, the success of crop rotation depends on information about the nematode species and races that occur in the area, and on the effect of these nematodes on the species and cultivars used, considering the multiplication capacity of these pathogens.

C. abysinica is little known and little studied in Brazil. However, results from researches on $C$. abyssinica can assist in the development of productive systems for this crop species. Information on the effects of root-knot nematodes on this crop is important when using crop rotation to control soil pathogens. Tavares-Silva et al. (2016) reported the effect of Meloidogyne javanica on C. abyssinica in Paraná, Brazil. However, studies with $M$. incognita are not found for $C$. abyssinica. Considering that the inoculation of different isolates (from Minas Gerais, Brazil) could result in different effects on $C$. abyssinica due to the intraspecific variability of $M$. javanica (MEDINA et al., 2017), the objective of this work was to evaluate the effect of different inoculum levels of $M$. incognita race 3 and $M$. javanica on $C$. abyssinica plants of the FMSBrilhante cultivar.

\section{MATERIAL AND METHODS}

Two experiments were conducted in a greenhouse of the Department of Agricultural Sciences of the State University of Montes Claros, Janaúba campus, in Montes Claros, state of Minas Gerais, Brazil $\left(15^{\circ} 47^{\prime} 50^{\prime \prime} \mathrm{S}, 43^{\circ} 18^{\prime} 321^{\prime \prime} \mathrm{W}\right.$, and altitude of $533 \mathrm{~m}$ ). The region has a dry winter and rainy summer. The effects of Meloidogyne javanica (Experiment 1), and M. incognita race 3 (Experiment 2) on Crambe abyssinica plants were evaluated from March to April, and October to November, respectively. The average minimum and maximum temperatures were, respectively, $11.8^{\circ} \mathrm{C}$ and $25.9{ }^{\circ} \mathrm{C}$ (Experiment 1), and $17.4{ }^{\circ} \mathrm{C}$ and $31.4{ }^{\circ} \mathrm{C}$ (Experiment 2).

The inoculums of $M$. javanica, and $M$. incognita race 3 were obtained from monospecific populations maintained for 60 days in tomato plants of the Kada cultivar (Santa Cruz group) grown in a greenhouse. The aerial parts of the plants were cut, their root systems washed, and the eggs extracted using the Hussey and Barker (1973) technique modified by Boneti and Ferraz (1981). The egg suspension was calibrated in a counting chamber at $350,700,1400,2800,5600$ eggs $\mathrm{mL}^{-1}$ using an inverted objective optical microscope.

C. abyssinica seeds of the FMS-Brilhante cultivar were seeded in polyethylene trays containing washed sand. The seedlings were transplanted at 11 days after planting to plastic pots containing $1.5 \mathrm{~L}$ of sandy soil. The soil used was classified as Fulvic Neossolo and presented $90 \mathrm{~g} \mathrm{~kg}^{-1}$ of clay, $860 \mathrm{~g} \mathrm{~kg}^{-1}$ of sand, $50 \mathrm{~g} \mathrm{~kg}^{-1}$ of silt, and $\mathrm{pH}$ of 7.1. The soil used to multiply the nematodes, obtain the $C$. abyssinica seedlings, and perform the tests were previously autoclaved at $120^{\circ} \mathrm{C}$ for 30 minutes for three consecutive days.

The soil was infested with different inoculum levels at one day after transplanting of the seedlings according to the treatments, with applications in four points of the pot, around the root system of the seedlings. The plants were maintained in a greenhouse with daily irrigation. A randomized block experimental design with five treatments (inoculum levels) and ten replications was used. The controls consisted of $C$. abyssinica plants without inoculation with nematode, and tomato plants of the Kada cultivar (Santa Cruz group) inoculated with 2000 eggs to test the viability of the inoculums. Each plot consisted of one pot with one seedling.

The number of root knots (NRK), number of egg masses (NEM), and number of eggs + second- 
stage juveniles (NEJ2) per root system, number of J2 per $200 \mathrm{~cm}^{3}$ of soil (NJ2), and shoot dry weight (SDW) of the inoculated $C$. abyssinica plants were evaluated at 45 days after inoculation. The number of eggs was used to calculate the reproduction factor (RF), which is the final divided by the initial population densities. The plants were classified according to the RF found, as described by Oostenbrink (1966) - plants with $\mathrm{RF}<1$ are resistant, plants with $\mathrm{RF}=0$ are immune, and plants with $\mathrm{RF} \geq 1$ are susceptible.

The plants were cut at the stem base, and the aerial part was dried in an oven at $65^{\circ} \mathrm{C}$ for 72 hours to determine their shoot dry weights. The roots were carefully washed in a bucket with water; stained with floxin B to count galls and egg masses (TAYLOR; SASSER, 1978); subjected to the technique used by Hussey and Barker (1973) and modified by Boneti and Ferraz (1981) to determine the number of eggs, and to the Jenkins (1964) technique for the extraction of juveniles. The numbers of eggs and juveniles were counted in a counting chamber using an inverted objective optical microscope.

The results were subjected to analysis of variance and the means were subjected to regression

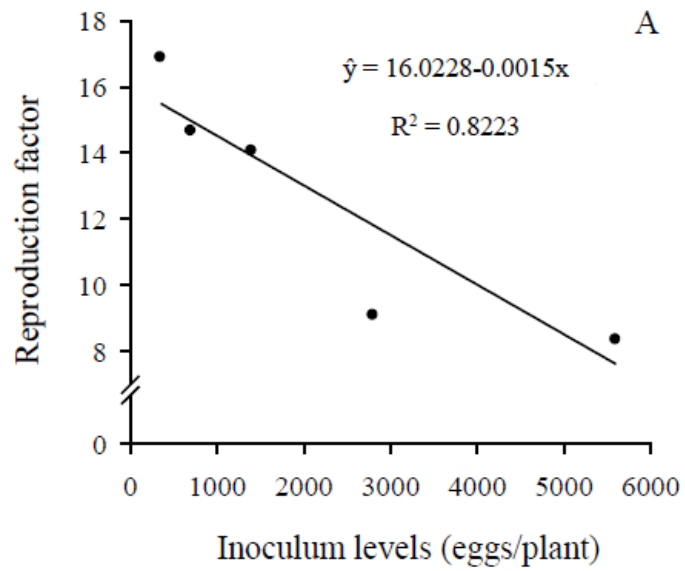

Figure 1. Reproduction factor of Meloidogyne incognita race 3 (A) and Meloidogyne javanica (B) in Crambe abyssinica plants of the FMS-Brilhante cultivar.

The inoculum levels had significant effect $(p<0,01)$ on the number of galls, number of egg masses, and number of eggs $+\mathrm{J} 2$ on roots, and number of $\mathrm{J} 2$ in the soil. All nematode variables analysis using the SISVAR program (FERREIRA, 2011). The graphics were developed using the SigmaPlot 11.0 program.

\section{RESULTS AND DISCUSSION}

The inocula of Meloidogyne javanica (Experiment 1) and $M$. incognita race 3 (Experiment 2) presented viability, with reproduction factors (RF) of 8.32 and 13.78 , respectively, in tomato plants. The RF of the two nematode species evaluated were higher than 1 in the Crambe abyssinica plants of the FMS-Brilhante cultivar, regardless of the inoculum level tested, denoting the susceptibility of the crop (Figure 1). The RF decreased significant with increasing number of nematodes inoculated for both nematodes, and were fitted by linear regression models.

The RF varied from 8.34 (with initial inoculum level of 5600 eggs) to 16.87 (with initial inoculum level of 350 eggs) for $M$. incognita race 3; and from 6.7 (initial inoculum level of 5600 eggs) to 20.4 (initial inoculum level of 350 eggs) for $M$. javanica.

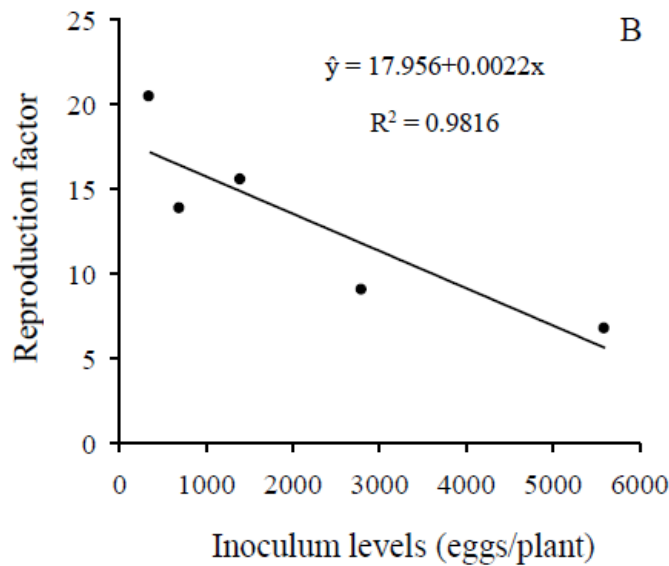

were fitted by linear regression models for Meloidogyne spp., presenting increases with increasing inoculum levels (Figures 2 and 3). 

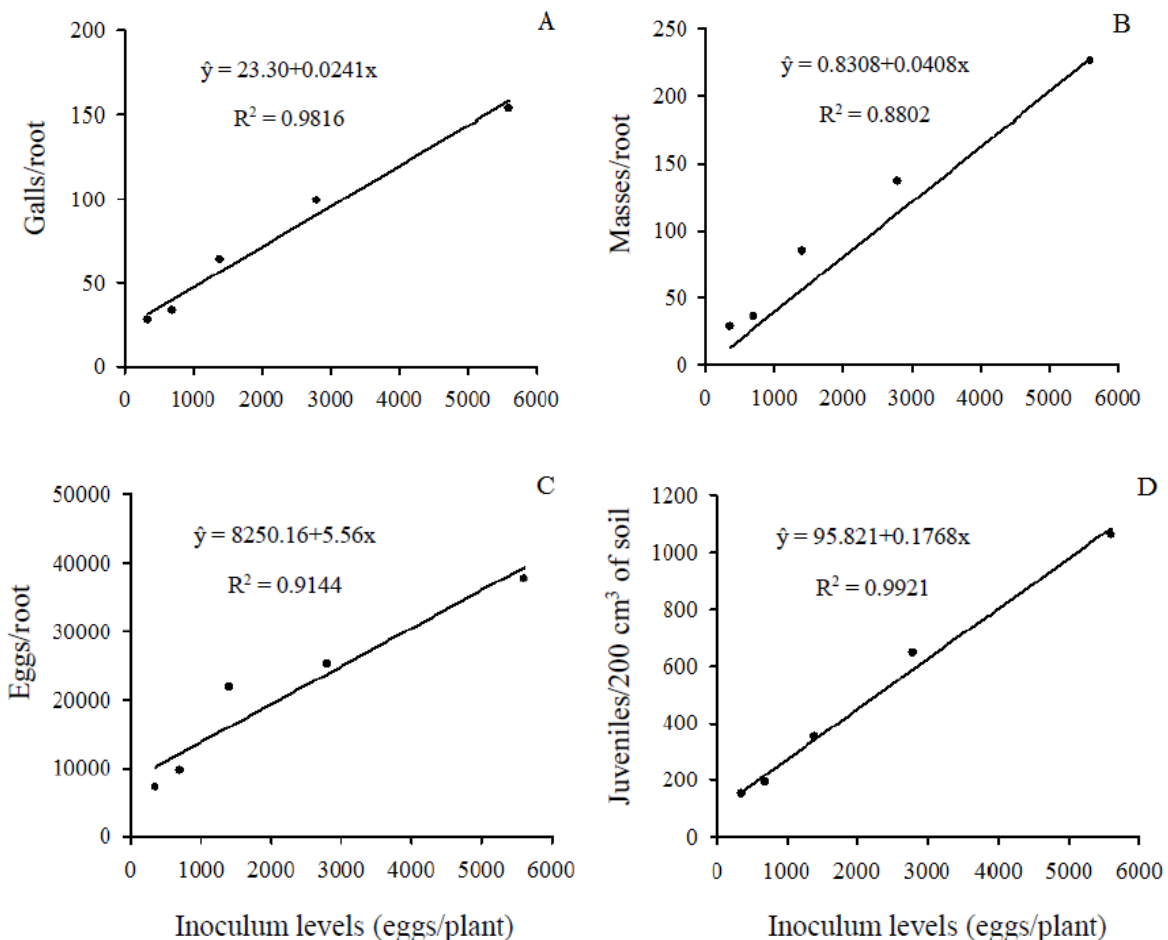

Figure 2. Numbers of galls (A), number of egg masses (B), and number of eggs + possible J2 (C) per C. abyssinica root, and number of juveniles per $200 \mathrm{~cm}^{3}$ of soil (D) at 45 days after inoculation with increasing egg levels of Meloidogyne javanica.
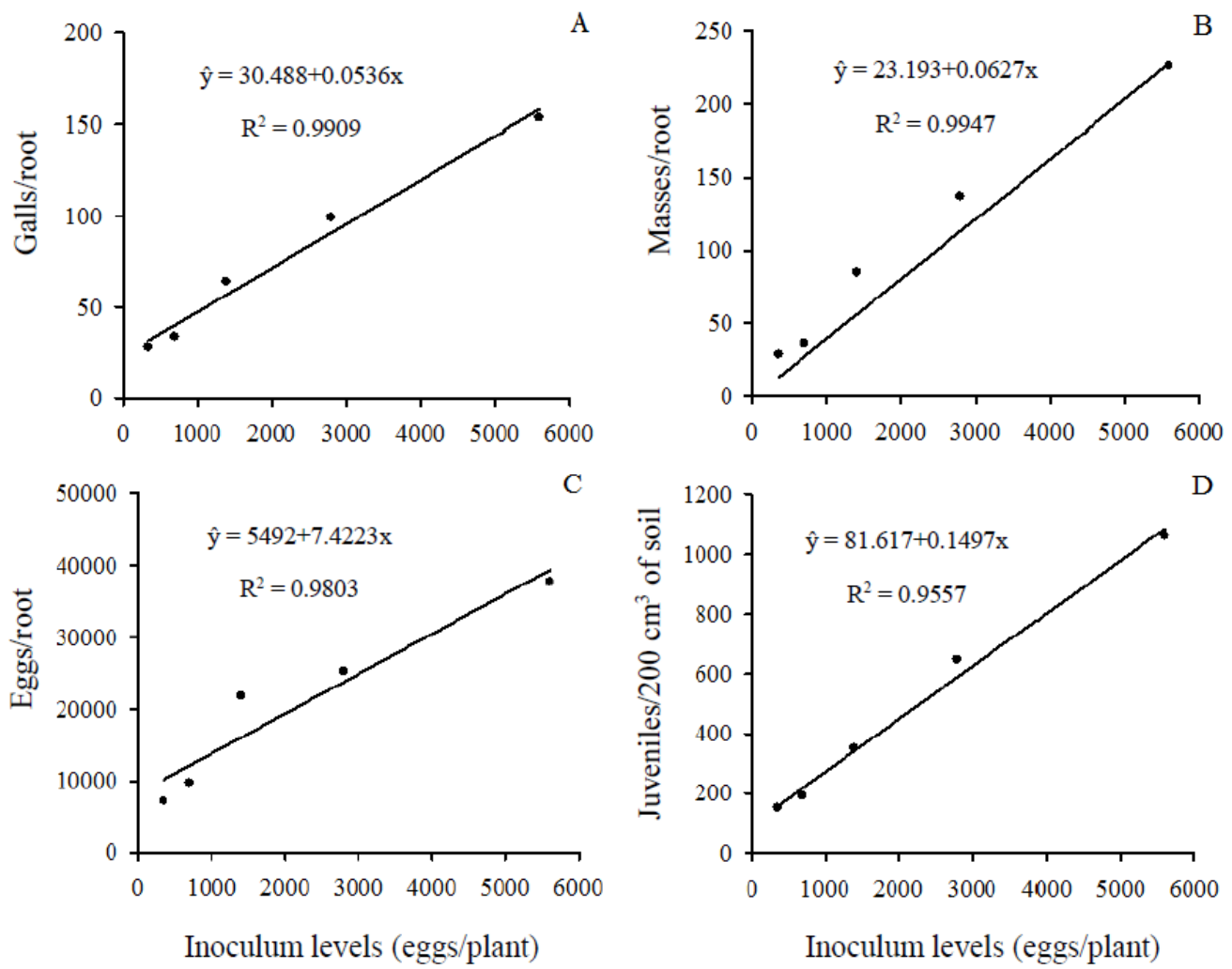

Figure 3. Numbers of galls (A), number of egg masses (B), and number of eggs + possible $\mathrm{J} 2$ (C) per C. abyssinica root, and number of juveniles per $200 \mathrm{~cm}^{3}$ of soil (D) at 45 days after inoculation with increasing egg levels of Meloidogyne incognita race 3. 
The nematode inoculum levels had no significant effect on the shoot dry weight (SDW) of the $C$. abyssinica plants. The SDW varied 1.0 to 1.2 $\mathrm{g}$ from that of non-inoculated plants $(1.5 \mathrm{~g})$ for $M$. javanica; and 2.3 to $2.5 \mathrm{~g}$ from that of noninoculated plants $(2.6 \mathrm{~g})$ for $M$. incognita race 3 . According to these results, the development of $C$. abyssinica plants was not compromised by the inoculum levels evaluated, characterizing them as tolerant to these nematodes (ROBERTS, 2002).

The inoculums of $M$. javanica, and $M$. incognita race 3 presented viability, with $\mathrm{RF} \geq 1$ in the tomato plants, indicating susceptibility (OOSTENBRINK, 1966). According to the results, $C$. abyssinica is susceptible to both root-knot nematodes, with $M$. incognita presenting higher RF when compared to that found in tomato plants. The $M$. javanica, and $M$. incognita race 3 had a decrease in RF with increasing initial inoculum level. Similar results have been found for $M$. incognita in sugarcane plants (SILVA et al., 2012) and for $M$. enterolobii in guava plants of the Paluma cultivar (BURLA et al., 2010). This reduction in RF with increasing inoculum level is due to the competition among nematodes that emerge in the root system in the different sites of infection (KAYANI; MUKHTAR; HUSSAIN, 2018).

Studies have shown that increases in initial nematode inoculum levels increase the number of root knots, number of egg masses, and number of eggs and juveniles of Meloidogyne spp. in passion fruits and tomato plants (EL-MOOR; PEIXOTO; TAMOS, 2009; BELAN et al., 2011). Increases in the number of eggs and juveniles of $M$. javanica in C. abyssinica are dependent on the season of the year, with greater susceptibility of this plant species in warmer seasons (TAVARES-SILVA et al., 2016).

The increasing inoculum levels of $M$. javanica had no effect on the SDW of the $C$. abyssinica plants under the conditions evaluated. Tavares-Silva et al. (2016) also found no negative impact of $M$. javanica on shoot fresh weight, shoot dry weight, plant height, and seed oil content in experiments with $C$. abyssinica conducted under minimum average temperatures of $21.2^{\circ} \mathrm{C}$ and 12.9 ${ }^{\circ} \mathrm{C}$, and maximum averages of $31.9{ }^{\circ} \mathrm{C}$ and $21.7{ }^{\circ} \mathrm{C}$, in Paraná, Brazil. Decreases in the development of other plant species with increasing initial inoculum of Meloidogyne spp. have been observed with high inoculum levels (10,000 and 20,000 eggs per $\mathrm{kg}$ of soil) on sugarcane plants of the SP81-3250 cultivar, with significantly decreases in shoot fresh weight when compared to the control (SILVA et al., 2012). Similarly, increasing $M$. javanica inoculum level reduced the vegetative development of cherry tomato plants of different genotypes (BELAN et al., 2011). Increasing inoculum levels of Meloidogyne spp. also decreased the SDW of inoculated okra plants (HUSSAIN; MUKHTAR; KAYANI, 2011).

\section{CONCLUSION}

Crambe abyssinica plants are susceptible to the different levels of inoculum of Meloidogyne javanica, and $M$. incognita used, however, their development is not affected by nematode infections.

\section{ACKNOWLEDGEMENTS}

The authors thank the Minas Gerais State Agency for Research and Development (FAPEMIG) for granting scholarships (BIPDT).

\section{REFERENCES}

AIR Crambe abyssinica, a comprehensive program Workshop - Part 4 - Production and utilization. Summary information. AIR3-CT94-2480, 1997.

BELAN, L. L. et al. Efeitos de densidades crescentes de inóculos de $M$. javanica no desenvolvimento de tomateiro cereja. Revista Trópica- Ciências Agrárias e Biológicas, v. 5, n. 1, p. 22-30, 2011.

BONETI, J. I. S.; FERRAZ, S. Modificação do método de Hussey e Barker para extração de ovos de Meloidogyne exigua de cafeeiro. Fitopatologia Brasileira, v. 6, n. 3, p. 553, 1981.

BURLA, R. S. et al. Comparação entre níveis de inóculo, épocas de avaliação e variáveis para seleção de Psidium spp. visando a resistência a Meloidogyne mayaguensis. Nematologia Brasileira, v. 34, n. 2, p. 82-90, 2010.

EL-MOOR, R. D.; PEIXOTO, J. R.; TAMOS, M. L. G. Reação de genótipos de maracujazeiro-azedo aos nematoides de galhas (Meloidogyne incognita e Meloidogyne javanica). Bioscience Journal, v. 25, n. 1, p. 53-59, 2009.

FALASCA, S. L. et al. Crambe abyssinica: An almost unknow crop with a promissory future to produce biodiesel in Argentina. International Journal of Hydrogen Energy, v. 35. n. 11, p. 5808$5812,2010$.

FERREIRA, D. F.Sisvar: a computer statistical analysis system. Ciência e Agrotecnologia, v. 35, n. 6, p. 1039-1042, 2011.

FREITAS, L. G.; FERRAZ, S. O. Controle de fitonematoides por plantas antagonistas e produtos naturais. Disponível em: <https:// www.researchgate.net/publication/255617363>.

Acesso em: 23 abri. 2007. 
HUSSAIN, M. A.; MUKHTAR, T.; KAYANI, M. Z. Assessment of the damage caused by Meloidogyne incognita in okra (Abelmoschus esculentus). The Journal of Animal \& Plant Scxiences, v. 21, n. 4, p. $857-861,2011$.

HUSSEY, R. S.; BARKER, K. R. A comparison of methods of collecting inocula of Meloidogyne spp., including a new technique. Plant Disease, v. 57, n. 12, p. 1025-1018, 1973.

JENKINS, W. R. A rapid centrifugal- flotation technique for separation nematodes from soil. Plant Disease Reporter, v. 48, n. 2, p. 692, 1964.

KAYANI, M. Z.; MUKHTAR, T.; HUSSAIN, M. A. Interaction between nematode inoculum density and plant age on growth and yield of cucumber ad reproduction of Meloidogyne incognita. Pakistan Journal of Zoology, v. 50, n. 3, p. 897-902, 2018.

MEDINA, I. L. et al. Genetic diversity of Meloidogyne spp. Parasiting potato in Brazil and aggressiveness of $M$. javanica populations on susceptible cultivars. Nematology, v. 19, n. 1, p. 69$80,2017$.

OOSTENBRINK, M. Major characteristics of the relation between nematodes and plants. Mededeelingen, v. 66, n. 3, p. 1-46, 1966.

PITOL, C.; BROCH, D. L.; ROSCOE. R. Tecnologia e Produção: Crambe. Maracaju, MS: Fundação MS, 2010. 60 p.

REGINATO, P. et al. Desempenho agronômico e qualidade de sementes de crambe em diferentes épocas e profundidades de semeadura. Pesquisa Agropecuária Brasileira, v. 48, n. 10, p. 14101413, 2013

ROBERTS, P. A. Concepts and consequences of resistance In: Starr, J.L; Cook, R.; Bridge, J. (Eds.) Plant resistance to parasitic nematodes. Wallingford, UK: CAB International, 2002. p. 25-41.

ROSCOE, R.; DELMONTES, A. M. A. Crambe é nova opção para biodiesel. Agrianual 2009. São Paulo, SP: Instituto FNP, 2008. 40-41 p.

SILVA, A. P. et al. Reação de variedades de cana-de -açúcar ao parasitismo de Meloidogyne incognita e M. enterolobii. Revista Brasileira de Ciências Agrárias, v. 7, Sup., p. 814-819, 2012.

TAVARES-SILVA, C. A. et al. Reproduction of Meloidogyne javanica in crambe plant and influence on crop yield and oil content. African Journal of Agricultural Research, v. 11, n. 45, p. 4639-4645,
2016.

TAYLOR, A. L.; SASSER, J. N. Biology, identification and control of root knot nematodes (Meloidogyne spp.). Raleigh: North Caroline State University, 1978. $111 \mathrm{p}$.

WALTER, J. T. Crambe and rapseedd meal as soil amendments: nematicidal potential and phytotoxic effects. Crop Protection, v. 15, n. 5, p. 433-437, 1996

This work is licensed under a Creative Commons Attribution-CC-BY https://creativecommons.org/licenses/by/4.0/ 